Note

\title{
DAMAGE CAUSED BY CAPYBARAS IN A CORN FIELD
}

\author{
Katia Maria Paschoaletto Michi de Barros Ferraz ${ }^{1}$; Marrie-Anne Lechevalier ${ }^{1}$; Hilton Thadeu \\ Zarate do Couto2; Luciano Martins Verdade ${ }^{1 *}$ \\ ${ }^{1}$ Depto. de Produção Animal - Lab. de Ecologia Animal - USP/ESALQ, C.P. 9 - CEP: 13418-900 - Piracicaba, SP. \\ ${ }^{2}$ Depto. de Ciências Florestais - USP/ESALQ, C.P. 530 - CEP: 13418-970 - Piracicaba, SP. \\ *Corresponding author <Imv@esalq.usp.br>
}

\begin{abstract}
Damage caused by capybaras in agroecossystems in Brazil has been frequently observed. The objective of this study was to describe and quantify the actual damage caused by capybaras in a corn field, aiming to get basic information on how, how much, and where these damage occur. Systematic sampling indicated that $26 \%$ of the planted area were damaged by capybaras, and the highest percentage of damage occurred on the border of the corn field $(t=4.5698, p=0.0001)$. Damage in areas adjacent to a forest fragment was significantly higher $(t=13.6198, p=0.0001)$, suggesting that the strategy of area utilization for feeding was related to the proximity of the resources "forest" and "water". Avoiding corn plantation in areas adjacent to forest fragments used by capybaras and, when possible, controlling capybara population may lead to a reduction of damage occurrence in agroecossystems.

Key words: Hydrochaeris hydrochaeris, GIS, crop damage, agroecossystems
\end{abstract}

\section{DANOS CAUSADOS POR CAPIVARAS EM UM CAMPO DE MILHO}

\begin{abstract}
RESUMO: Danos causados por capivaras em culturas agrícolas no Brasil têm sido freqüentemente reportados. O objetivo deste estudo foi descrever e quantificar os danos causados por capivaras em um campo de milho, visando obter informações básicas de quanto, como e onde esse dano ocorre. Através da amostragem sistemática obteve-se que $26 \%$ da área plantada foi danificada por capivaras, sendo que a maior porcentagem dos danos localizou-se nas bordas do campo de milho ( $\mathrm{t}=4.5698, \mathrm{p}=0.0001)$. O dano em áreas adjacentes ao fragmento de mata foi significativamente maior do que no restante do terreno ( $t=13.6198, p=0.0001$ ), sugerindo que a estratégia de utilização da área de alimentação pela capivara relaciona-se com o fator proximidade dos recursos "floresta" e "água". Evitar o plantio de milho em áreas adjacentes a fragmentos florestais utilizados por capivaras e, quando possível adotar práticas de controle populacional, podem significar a redução da ocorrência de danos causados aos agroecossistemas.

Palavras-chave: Hydrochaeris hydrochaeris, SIG, dano agrícola, agroecossistemas
\end{abstract}

\section{INTRODUCTION}

The need for a damage control caused by wild species has been considerably growing in the last years, mainly due to the expansion of human activities and the intensive land use (Dolbeer et al., 1996). The alteration process of the original landscape can have a direct or indirect influence on the pattern of distribution and abundance of the species (Wiens, 1996). Therefore, some wild species tend to find favorable conditions to their survival, increasing their populations and causing damage to agriculture and pastures.

Cases of damage caused by wildlife in agricultural fields and forest areas are significantly increasing lately (Mello Filho et al., 1981; Matschke et al., 1984; Dolbeer et al., 1996; Wywialowski, 1996; Mower et al., 1997a, b; Wagner et al., 1997; Bulinski \& McArthur, 1999; Reimoser et al., 1999). Nevertheless, the damage is usually difficult to measure. In general, they involve livestock predation and agricultural losses. In the case of capybaras, the damage is related to herbivory in agricultural crops, since this species uses these areas as food source.
The capybara (Hydrochaeris hydrochaeris, Rodentia: Caviomorpha) (Linnaeus, 1766) is spread all over tropical America (Azcarate, 1980; Emmons, 1990; Ojasti, 1973) in several kinds of environments (Moreira \& Macdonald, 1997). In general, its habitat is formed by a small forest area, used for resting, sheltering and parturition; a grazing land, used for feeding; and a permanent water course used for copulation, resting and predator escape (Ojasti, 1973; Azcarate, 1980; Macdonald, 1981; Alho et al., 1989). The pattern of habitat use changes seasonably (Alho \& Rondon, 1987) following the availability of water, and grass (Herrera \& Macdonald, 1989). However, the seasonable changes in habitat use does not involve migratory movements.

The capybara is herbivorous, feeding on grass and water plants (Ojasti, 1973). However caybaras have been showing high adaptation capacity to agroecossystems because of their high feeding plasticity. This pattern, possibly associated with the disappearance of its natural predators, has changed capybara into an agricultural pest in some places. Although empiric reports on damage caused by capybaras are relatively 
frequent, no systemized study has been done yet. Damage quantification specially when it has a significant economic impact, is essential for the settlement of adequate policy for the species management and control in agricultural areas (Wywialowski, 1996). In the province of Corrientes, Argentina, for instance, the Fauna Service allows the controlled hunting of capybara populations associated with damage to agriculture and grasslands (Ojasti, 1991).

This study had the purpose of describing and quantifying the damage caused by capybaras in a corn field, including information on how much and where damage occurred.

\section{MATERIAL AND METHODS}

This study was carried out in a corn field (4.5 ha) located in "Fazenda Areão" agricultural station of the University of Sao Paulo (132.59 ha), in Piracicaba, (2242'30" S and 473' $30^{\prime \prime}$ W; 546 m high) SP, Brazil. The station has also experimental fields of sugar cane, bean, soybean, cotton, rubber tree, Eucaliptus ssp and Pinus ssp. It has also a fragment of a native semideciduous forest (7 ha) and a dam (1.7 ha).

A preliminary survey showed that the corn field, adjacent to the forest and next to the dam, was the main damaged area. The use of this area by capybaras was characterized by the great amount of vestiges, such as scats and footprints, and also by the direct observation of the animals. Damage included broken, partially eaten, and entirely eaten corn plants.

The damage was evaluated on a single day, a week before harvest, by systematic sample method (Cochran, 1963); 84 patches of $9 \mathrm{~m}^{2}$ each were distributed through the corn field following plant rows. A constant of $10 \mathrm{~m}$ distance was established between patches and a distance of $33.5 \mathrm{~m}$ was established between rows, excluding terraces $(3-6 \mathrm{~m})$. The total number of corn plants and the total number of damaged plants (eaten + broken) were counted in each patch obtaining the percentage of damage in each patch. It was necessary to count the total number of corn plants in each patch because they were not homogeneous in relation to the number of corn plants. The results were analyzed by the Student test (5\%), in SAS System (SAS, 1996), to compare border and core areas of the field. Similarly, it was possible to compare damage in adjacent and nonadjacent areas in relation to the forest.

The patches were plotted into the area map by the Geographic Information System Arc View GIS 3.2 (ESRI, 1996). Damage percentages were interpolated by the linear krigging method to obtain a map of spatial distribution of the damage. This method uses a probability model which calculates the bias and the error variance, choosing weights to proximate samples that assure the medium model error to be exactly zero and the modeled error variance to be minimized (Isaaks \& Srivastava, 1989).

\section{RESULTS AND DISCUSSION}

About a quarter (26.5\%) of the field was damaged by capybaras. Most of the damage occurred on the boarder between the corn field and the forest $(t=4.5698, p=0.0001)$ and to open area around the dam (Figure 1). The damage adjacent to the forest significantly differed from the damage in the rest of the field ( $t=13.6198, p=0.0001)$. However, damage also occurred in the opposite side of the forest (Figure 1) where, there was a small wetland. The presence of animals in this side can possibly explain the damage in patches adjacent to the pond.

The damage reduces dramatically as distance from the dam to the forest increases (Figure 1), suggesting that damage distribution is not random. The proximity of the corn field in relation the species habitat is the most likely cause of its use by the capybara (Ojasti, 1973). This strategy can be related to the proximity factor of forest and water resources, generally present in capybara's natural habitats (Ojasti, 1973; Macdonald, 1981; Alho et al., 1989). The capybara uses water bodies for breeding activities and predator avoidance, and the forest for sheltering (Ojasti, 1973; Azcarate, 1980; Macdonald, 1981).

Wildlife damage is possibly related to population density (Matschke et al., 1984; Motta, 1996). According to Motta (1996), high densities of ungulates are usually related to damage intensity, but not to its incidence. This pattern is likely to be happening in this study area. The amount of food offered by agricultural crops can increase the resources availability for a species (Lacher et al., 1998), increasing capybaras population density, and consequently, increasing crop damage even more.

A possibility to reduce wildlife impact is the management of animals on its own habitat, controlling its population density by the periodical exploitation of individuals (Ojasti, 1973; Matschke et al., 1984; McNulty et al., 1997; Shea et al., 1998). Sustainable hunting can maintain the population density below damage level, but as close as possible to its maximum sustainable yield (Caughley \& Sinclair, 1994). The success of such a program is related to the establishment of an ideal exploitation level as close as possible to the population maximum growth rate (Robinson \& Redford, 1991). The establishment of such a program requires periodical population monitoring and adaptive quotas of exploitation.

In spite of legal restrictions in Brazil, harvesting is being considered as a rational alternative, since the capybara is one of the South-American species with the greatest potential for sustainable management (Moreira \& Macdonald, 1997). The decline of capybara population density can result in the consequent reduction of the specie damage to agriculture in areas where it occurs.

Changing human practices or attitude to the wildlife can eventually be considered as possible alternatives (Matschke et al., 1984; Wagner et al., 1997). 


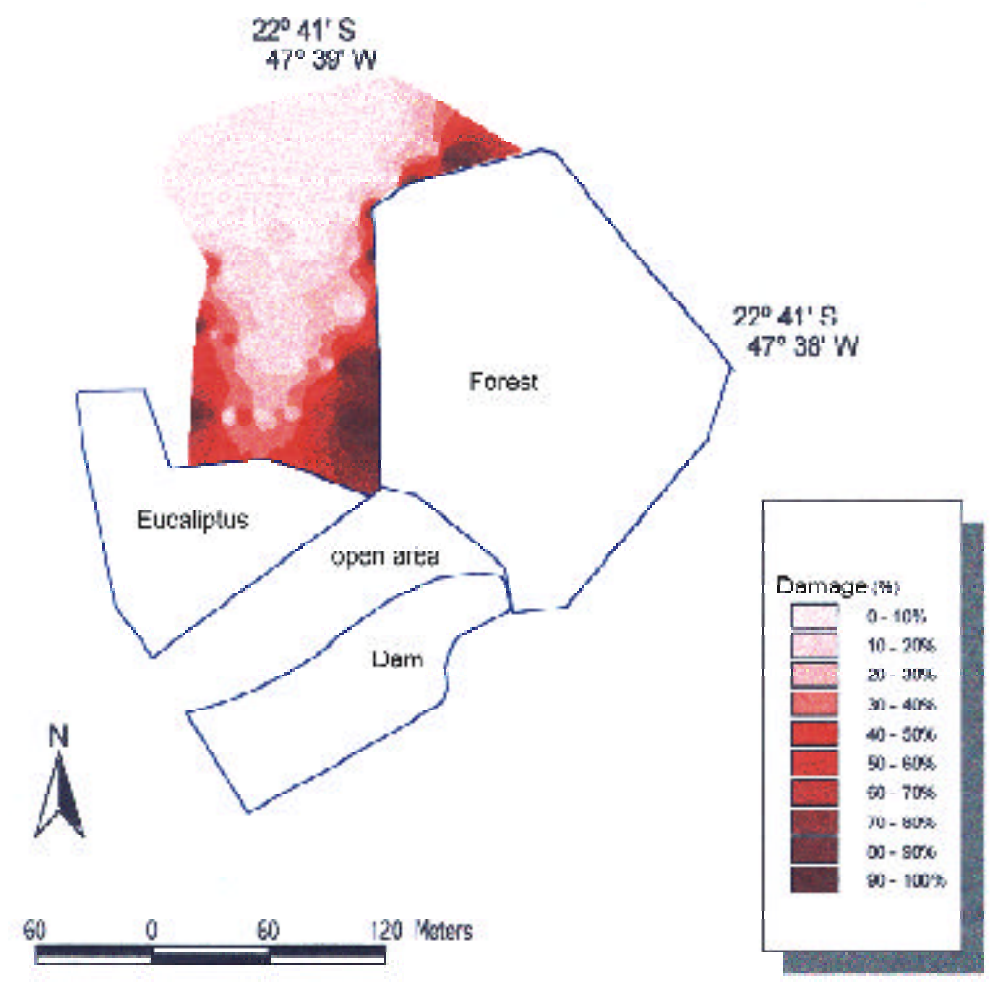

Figure 1 - Spatial distribution of the damage caused by capybaras in a corn field, and its proximity to other landscape elements (Method: Linear Krigging: ArcView GIS 3.2).

Planting corn far from forest fragments and water bodies might reduce damage as well. Another possibility is planting a surplus of the same culture, which can provide the basic needs for the animals. Matschke et al. (1984), for instance, suggests the plantation of food items attractive to deer in order to keep them far from commercial crop. Wagner et al. (1997) suggests the establishment of economic compensatory programs in order to increase human tolerance to wildlife damage.

The key factor for any management program is the search for local alternatives, which makes possible maintaining wildlife close to humans. Therefore, management actions must be based not only on ecological principles but also on socio economic aspects (Dolbeer et al., 1996).

\section{ACKNOWLEDGEMENTS}

We would like to thank the Prefeitura do Campus "Luiz de Queiroz", in special Prof. Dr. Marcos V. Folegatti and Mr. Luiz Fernando S. Marchiori for logistical support. We also would like to thank Silvio F. B. Ferraz for his support on the use of Geographic information System. Cristiane G. Caldana, Roberto M.F. Santos Filho and Társis R. O Piffer participated to the field work. The present study has been partially supported by Fundação de Amparo à Pesquisa do Estado de São Paulo - FAPESP (Procs Nos. 00/00180-9, 00/00602-0, 00/00582-0).

\section{REFERENCES}

ALHO, C.J.R.; RONDON, N.L. Habitats, population densities and social structure of capybaras (Hydrochaeris hydrochaeris: Rodentia) in the Pantanal, Brasil. Revista Brasileira de Zoologia, v.4, p.139-149, 1987.

ALHO, C.J.R.; CAMPOS, V.M.; GONÇALVES, H.C. Ecology, social behavior and management of the capybara in the Pantanal of Brazil. Advances in Neotropical Mammalogy, p.163-194, 1989.

AZCARATE, T. de. Sociobiologia y manejo del capibara Hydrochoerus hydrochaeris). Donana Acta Vertebrata, v.7, p.1-228. 1980

BULINSKI, J.; MCARTHUR, C. An experimental field study of the effects of mammalian herbivore damage on Eucalyptus nitens seedlings. Forest Ecology and Management, v.113, p.241-249, 1999.

CAUGHLEY, G.; SINCLAIR, A.R.E. Wildlife ecology and management. Boston: Blackwell Science Publications, 1994. 334p.

COCHRAN, W.G. Sampling techniques. 2.ed. New York: Wiley, 1963. 413p.

DOLBEER, R.A.; HOLLER, N.R.; HAWTHORNE, D.W. Identification and control of wildlife damage. In: BOOKHOUT, T.A. (Ed.) Research and management techniques for wildlife and habitats. Bethesda: The Wildlife Society, 1996. p.474-506.

EMMONS, L.H. Neotropical rainforest mammals: a field guide. Chicago: University Press, 1990. $281 \mathrm{p}$.

ESRI - Environmental Systems Research Institute. Using ArcView GIS. New York: ESRI Press. 1996. 340p.

HERRERA, E.A.; MACDONALD, D.W. Resource utilization and territoriality group-living Capybaras (Hydrochoerus hydrochaeris). Journal of Animal Ecology, v.58, p.667-679, 1989.

ISAAKS, E.; SRIVASTAVA, R.M. Applied geoestatistics. Oxford: University Press, 1989. 561p.

LACHER, T.E., Jr.; SLACK, R.D.; COBURN, L.M.; GOLDSTEIN, M.I. The role of agroecosystems in wildlife biodiversity. In: COLLINS, W.W.; QUALSET, C.O. (Ed.) Biodiversity in Agroecosystems. Boca Raton: CRC Press, 1998. p.147-165.

MACDONALD, D.W. Dwindling resources and the social behaviour of capybara, (Hydrochoerus hydrochaeris) (Mammalia). Journal of Zoological Society of London, v.194, p.371-391, 1981.

MATSCHKE, GH.; DE CALESTA, D.S.; HARDER, J.D. Crop damage and control. In: HALLS, L. K. (Ed.) White-tailed deer. Ecology and management. A Wildlife Management Institute Book. Harrisburg: Stackpole Book, 1984. p.647-654. 
MCNULTY, S.A.; PORTER, W.F.; MATHEWS, N.E.; HILL, J.A. Localized management for reducing white-tailed deer populations. Wildlife Society Bulletin, v.25, p.265-271, 1997.

MELLO FILHO, J.A. STOEHR, G.W.D.; FABER, J. Determinação dos danos causados a sementes e mudas de Aruacaria augustifolia (Bert.) O. Ktze. Nos processos de regeneração natural e artificial. Revista Floresta, v.12, p.26-43, 1981.

MOREIRA, J.R.; MACDONALD, D.W. Técnicas de manejo de capivaras e outros grandes roedores na Amazônia. In: VALLADARES-PADUA, C.; BODMER, R.E.; CULLEN Jr., L. (Ed.) Manejo e conservação de vida silvestre no Brasil. Belém: Sociedade Civil Mamirauá, 1997. p.186-213.

MOTTA, R. Impact of wild ungulates on forest regeneration and tree composition of mountain forests in the Western Italian Alps. Forest Ecology and Management, v.88, p.93-98, 1996.

MOWER, K.J.; TOWNSEND, T.W.; TYZNIK, W.J. Sample sizes to measure young apple trees browsed by deer in Ohio. Wildlife Society Bulletin, v.25, p.334-347, 1997a.

MOWER, K.J.; TOWNSEND, T.W.; TYZNIK, W.J. White-tailed deer damage to experimental apple orchards in Ohio. Wildlife Society Bulletin, v.25, p.337-343, 1997b.

OJASTI, J. Estudio biologico del chigüire o capibara. Caracas: Ed. Fondo Nacional de Investigaciones Agropecuarias, 1973. 257p.

OJASTI, J. Human exploitation of capybara. In: ROBINSON, J.G.; REDFORD, K.H. (Ed.) Neotropical wildlife use and conservation. Chicago: University Press, 1991. p.236-252.
REIMOSER, F.; ARMSTRONG, H.; SUCHANT, R. Measuring forest damage of ungulates: what should be considered. Forest Ecology and Management, v.120, p.47-58, 1999.

ROBINSON, J.G., REDFORD, K.H. Sustainable harvest of neotropical forest animals. In:ROBINSON, J.G.; REDFORD, K.H. (Ed.) Neotropical wildlife use and conservation. Chicago: University Press, 1991. p.415-429.

SAS Institute. SAS System. Release 6.12. Cary: Statistical Analysis System Institute, 1996

SHEA, K.; AMARASEKARE, P.; KAREIVA, P.; MANGEL, M.; MOORE, J.; MURDOCH, W.W.; NOONBURG, E.; PARMA, M.A.; PASCUAL, M.A.; POSSINGHAM, H.P.; WILCOX, C.; YU, D. Management of populations in conservation, harvesting and control. Tree, v.13, n.9, p. 371-375, 1998.

WAGNER, K.K.; SCHIMIDT, R.H.; CONOVER, M.R. Compensation programs for wildlife damage in North America. Wildlife Society Bulletin, v.25, p.312-319, 1997.

WIENS, J.A. Metapopulation dynamics and landscape ecology. In: HANSKI, I.A.; GILPIN, M.E. (Ed.) Metapopulation biology: ecology, genetics and evolution. São Diego: Academic Press, 1996. p.43-62.

WYWIALOWSKI, A.P. Wildlife damage to field corn in 1993. Wildlife Society Bulletin, v.24, p.264-271, 1996.

$\overline{\text { Received April 4, }}, 2001$ 